\title{
Hydrochemical and microbiological distinction and function of ombrotrophic peatland lagg as ecotone between Sphagnum peatland and forest catchment (Poleski National Park, eastern Poland)
}

\author{
Tomasz Mieczan $^{1 *}$, Monika Tarkowska-Kukuryk ${ }^{1}$ and Irena Bielańska-Grajner ${ }^{2}$ \\ 1 Department of Hydrobiology, University of Life Sciences, Dobrzańskiego 37, 20-262 Lublin, Poland \\ 2 Department of Hydrobiology, University of Silesia, Bankowa 9, 40-007 Katowice, Poland
}

Received 21 December 2011; Accepted 20 June 2012

\begin{abstract}
The testate amoeba, ciliate and rotifera communities living in interstitial waters in peatbog in eastern Poland were studied. Sampling was done on a monthly basis from April to November 2007-2008. Microbial communities were examined in a transect including three sites: (1) pine forest (site located $5 \mathrm{~m}$ from the lagg/forest contact zone), (2) lagg, (3) open peatbog (the centre of the peatbog). At each of the sites, interstitial water was sampled by means of piezometric wells placed to a depth of $1 \mathrm{~m}$. The species richness and abundance of protozoa and rotifers significantly differed between the studied stations, with the lowest numbers in the pine forest and the highest in the lagg. These differences between macro-habitats may be due to differences in environmental conditions. The distribution of samples in ordination space led to conclude that studied habitats are distributed along the falling gradient of $\mathrm{pH}$ and rising gradient of total organic carbon, water table depth and nitrate nitrogen. Assemblages of all three groups showed a strong compositional gradient correlated with water-table depth, conductivity and total phosphorus. However, species composition of ciliates and rotifers was explained by nitrate nitrogen and/or phosphates concentrations. The results suggest that lagg zone of a raised bog can fulfil the function of an ecotone zone, distinguished by a significant increase in biodiversity, abundance and species specificity of micro-organisms. It can also be a place of very efficient matter and energy flow in a peat bog ecosystem.
\end{abstract}

Key words: peatlands / lagg / ecotone / testate amoebae / ciliates / rotifers

\section{Introduction}

Quantifying the diversity and distribution of protozoa (testate amoebae and ciliates) and rotifers in aquatic habitats is important to gain a better understanding of microbial food webs in these systems. However, limnologists have paid little attention to peatlands, compared with other aquatic ecosystems (Gilbert and Mitchell, 2006). Peatlands, and especially Sphagnum-dominated peatlands, were at one time erroneously believed to be devoid of microbial life. In reality, and despite the successful use of Sphagnum as surgical dressings, diapers, or menstrual pads, Sphagnum mosses and peatlands support a high diversity of micro-organisms (Gilbert et al., 2000; Gilbert and Mitchell, 2006). In Sphagnum-dominated peatlands, the animal communities, especially invertebrate are sufficiently known (Borcard and Vaucher von Ballmoos, 1997).

\footnotetext{
*Corresponding author: tomasz.mieczan@up.lublin.pl
}

By contrast, little or no attention is given to abundance and biomass of protozoans and rotifers, and their relationships to environmental parameters in these specific ecosystems. The ecology of peatland testate amoebae is studied along broad gradient from very wet to dry micro-sites where testate amoebae are often found to respond primarily to the depth of water table (Lamentowicz et al., 2010; Jassey et al., 2011; Payne, 2011). Although the relationship between testate amoebae and DWT-depth of water table and others variables are well documented, much less is known about ciliates and rotifers in peatlands. These micro-organisms are important consumers of pico- and nano-sized producers, as well as important food sources to others metazoan (Mieczan, 2010, 2012; Wilkinson and Mitchell, 2010; Bielańska-Grajner et al., 2011). Wilkinson and Mitchell (2010) suggested that protozoa, even if only a minor fraction of the total microbial biomass, could be responsible for a large proportion of nutrient recycling in peatland communities. Metazoan grazing is important 
for recycling of nutrients and production of dissolved organic substrates for bacteria, but it is also a controlling factor for the protozoan community structure (Pierce and Turner, 1992; Mieczan, 2010, 2012; Wilkinson and Mitchell, 2010; Bielańska-Grajner et al., 2011).

A raised bog is not a uniform ecosystem. Several zones can be distinguished within its area, differing with a number of physical, chemical and biological factors. The dominant area of a peatbogs is the open bog, mainly occupied by Sphagnum and other peat-forming vegetation. In the case of many peatbogs, the open bog is surrounded by forest, and more specifically a forest catchment, i.e., an area of accumulation of all types of allochtonic materials. A raised bog also includes a zone separating the two areas. It is the laag area, i.e., a transitional zone between the ecosystem of the open peatbogs and the peatbogs catchment. The investigated area is generally distinguished by occurrence of nitrophilous vegetation, Cladietum marisci and Salix shrubs (Herbichowa and Potocka, 2004). So far, studies concerning physical and chemical water parameters in the agricultural catchment-lagg system were conducted only on the peatland at Lake Głębokie in the Mazurian Lakeland (Kruk, 2003). Due to a clear differentiation of chemical and biological conditions of the water in the horizontal arrangement, it seems that a similar differentiation should be expected in the case of testate amoebae, ciliates and rotifers. On the other hand, there are hardly any data concerning the horizontal distribution of protozoa and rotifers in interstitial waters. As the lagg zone is recognised as an ecotone (the contact zone between two different ecosystems - in this case between pine forest and peatland), it was assumed that it should show significant differences between physical and chemical water parameters from adjacent habitats, and be distinguished by high species richness of protozoa and rotifers, including occurrence of species typical of the zone. According to di Castri et al. (1988), ecotones are transitional zones between relatively homogenous areas or patches and characterized by high structural and spatial diversity. They are zones in which environmental gradients are steepened, where rates of change in ecological patterns and processes are increased relatively to the surrounding.

The primary objectives of this paper were: (i) to determine selected physical and chemical water parameters in the transect: pine forest catchment - lagg - open peatbog; (ii) to analyse the qualitative and quantitative structure of protozoa and rotifers in the horizontal forest catchment - lagg - peatbog; (iii) to determine whether the lagg waters differ in hydrochemical and microbiological terms from the waters of the forest catchment and the central part of the peatbog.

\section{Material and methods}

\section{Study site}

The study was performed in peatbog Durne Bagno located in the western part of the Polesie Lubelskie
(Eastern Poland, $51^{\circ} \mathrm{N}, 23^{\circ} \mathrm{E}$ ). Its borders encompass the most precious parts of Poleski National Park, including lakes and floodplains, as well as swamps and peatlands, which survived until now in a relatively unaltered shape. It is one of the most natural region of Poland, which was not covered by the last glaciation. The Durne Bagno is peatbog of continental type with hummock-hollow structure. It occupies the clearly distinguishable oval-shaped depression in sandy deposits. The western part of the depression is rather shallow and its eastern part reaches the depth of 7-8.5 m (Bałaga, 2007). The monthly average air temperatures of January and July are -4.1 and $17.9^{\circ} \mathrm{C}$, respectively, and the average annual total rainfall is $551 \mathrm{~mm}$. The first sampling area (pine forest) was characterized by the presence of Pinus sylvestris (L.), Molinia coerulera (L.) and Calamagrostis epigeios (L.) The second sampling area (lagg) is a contact zone between forest and open peatland with mixed vegetation: $C$. marisci (All.), Carex gracilis Curt., Sphagnum angustifolium (C.C.O. Jensen ex Russow), Sphagnum cuspidatum Ehrh. ex Hoffm. and Phragmites australis (Cav.Trin. ex Steud). Currently, the open peatbog (third sampling area) is overgrown by sparse pine-birch forest, with pine predominant in the central, highest part. The proportion of birch is higher to the marginal belt of peatbog. The vegetation is dominated by graminoids such as Eriophorum vaginatum (L.), Carex acutiformis Ehrhart., C. gracilis Curt. and S. angustifolium (C.C.O. Jensen ex Russow), S. cuspidatum Ehrh. ex Hoffm., Sphagnum flexuosum Dozy \& Molk., Sphagnum magellanicum Bird. and Polytrichum sp.

\section{Microbial communities sampling and identification}

Microbial communities were examined in a transect including: (1) pine forest (site located $5 \mathrm{~m}$ from the lagg/ forest contact zone - PF), (2) lagg (LG), (3) open peatbog (the centre of the peatland-OP) (Fig. 1). The samples were taken once a month from April to November 2007-2008. Collected data were presented in three seasons: spring (April, May and June), summer (July, August) and autumn (September, October and November). Mean values per season were presented in results due to the lack of significant differences between studied months.

During each sampling occasion three samples were collected from each site (peatbog, lagg and pine forest). At each of the sites, free water (water between bryophytes on the surface) and interstitial water were sampled by means of piezometric wells placed to a depth of $1 \mathrm{~m}$. Water collected in the piezometric wells during 2-4 min was then sampled by means of a syringe equipped with a rubber tube, and poured into plastic containers with a capacity of $100 \mathrm{~mL}$. Next, the samples were preserved with Lugol's iodine, and stored in dark at a temperature of $4{ }^{\circ} \mathrm{C}$. The abundance of testate amoebae, ciliates and rotifers and their community composition were determined using the Utermöhls method. For rotifers 2 L samples were filtered through plankton net of $10 \mu \mathrm{m}$ mesh size. Protozoa 


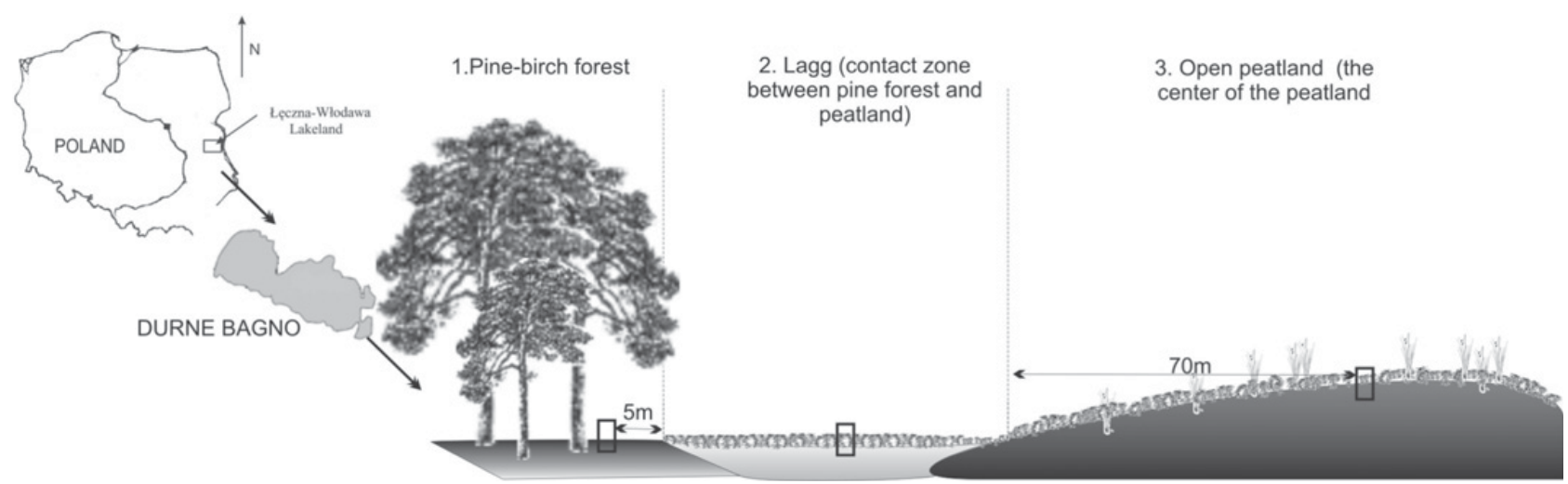

Fig. 1. Location of the sampling point.

(testate amoebae and ciliates) samples (whole sample $=$ $500 \mathrm{~mL}$ ) were sedimented for $24 \mathrm{~h}$ in cylinder, closed with parafilm, then the upper layer was gently removed. To determine the density, three samples were preserved with Logol's solution. Observation of live samples was used for the taxonomic and trophic identification. Ciliates are highly perishable, and the type of motility is a speciesspecific feature; for this reason, species determination and measurements were carried out on live material immediately after return to the laboratory and after silver impregnation (Augustin et al., 1984). Morphological identifications were mainly based on works by Foissner and Berger (1996), Foissner et al. (1999), Charman et al. (2000) and Clarke (2003).

\section{Abiotic variables}

Once a month, the water samples (volume of $500 \mathrm{~mL}$ ) for chemical analyses were taken. Temperature, conductivity, $\mathrm{pH}$ and dissolved oxygen (DO) were determined in situ with a multiparametric probe, total organic carbon (TOC) was determined using the spectrophotometer PASTEL UV and the remaining factors (TP-total phosphorus, $\mathrm{P}-\mathrm{PO}_{4}, \mathrm{TN}$ - total nitrate, $\mathrm{NH}_{4}, \mathrm{~N}-\mathrm{NO}_{3}$ ) were analysed in the laboratory (Golterman, 1969).

\section{Data analyses}

Diversity analysis [Shannon Wiener diversity index $\left(\log _{10}\right.$-based)] was performed using the Multivariate Statistical Package-MVSP (Kovach Computering Services, 2002).

The differences between physical and chemical water parameters among studied habitats were analysed by means of one-way ANOVA. Tukey's multiple range test (at $P<0.05$ ) was used to compare means when significant differences were found. The analysis was performed using PAST software. Spearman's rank correlation coefficients $(R)$ were calculated for pairs of environmental variables to recognize which of these variables are inter-correlated.

Detrended correspondence analysis (DCA) was used to measure and illustrate the variability gradients indicated by testate amoebae, ciliates and rotifers. Variables whose level of significance exceeded 0.05 were plotted passively on the diagrams. As the length of the gradient was $>2$ standard deviations, canonical correspondence analysis (CCA) was used to explore the relationships between the abundance of taxonomic groups and environmental variables (ter Braak and Šmilauer, 2002). Automatic forward selection of environmental variables, Monte Carlo permutation test (999 permutations) was used to determine the most important variables (Lepš and Šmilauer, 2003). Variables whose level of significance exceeded 0.05 were plotted passively on the diagrams. On the resultant plot, the arrows representing the physico-chemical variables indicate the direction of maximum change of that variable, and the length of each arrow is proportional to the rate of change. The proportion of variance explained by environmental variables was quantified using variance partitioning. The analysis was repeated in all sampling areas and separately for each of studied habitat. The ordination analyses were performed by means of CANOCO 4.5 for Windows.

\section{Results}

\section{Abiotic variables}

The water level was highly variable among sites and samples, ranging 4-25 cm above the surface (ANOVA, $F=27.2, \quad P=0.001)$. Statistically significant differences between the investigated sites (pine forest, lagg and open peatbog) were found in $\mathrm{pH}$, conductivity, nutrients and TOC (ANOVA, $F=26.22-29.71, P=0.001$ ). Water $\mathrm{pH}$ fluctuated from 2.9 in open peatbog to 7.1 in pine forest. In turn, conductivity was significantly differentiated, attaining from $32 \pm 6.1 \mu \mathrm{S} . \mathrm{cm}^{-1}$ in open peatbog to $487 \pm$ $82.7 \mu \mathrm{S} . \mathrm{cm}^{-1}$ in pine forest. The highest conductivity occurred in spring and summer, but was decidedly lower in autumn. In all sites examined, the water temperature reached the highest value in summer $\left(11.0-17.0 \pm 2.9^{\circ} \mathrm{C}\right)$, and decreased in autumn $\left(4.0-11.0 \pm 1.9^{\circ} \mathrm{C}\right)$. The highest concentration of TOC occurred in the lagg ( $>77 \pm 8 \mathrm{mgC} . \mathrm{L}^{-1}$, mean from three sites) and the lowest 


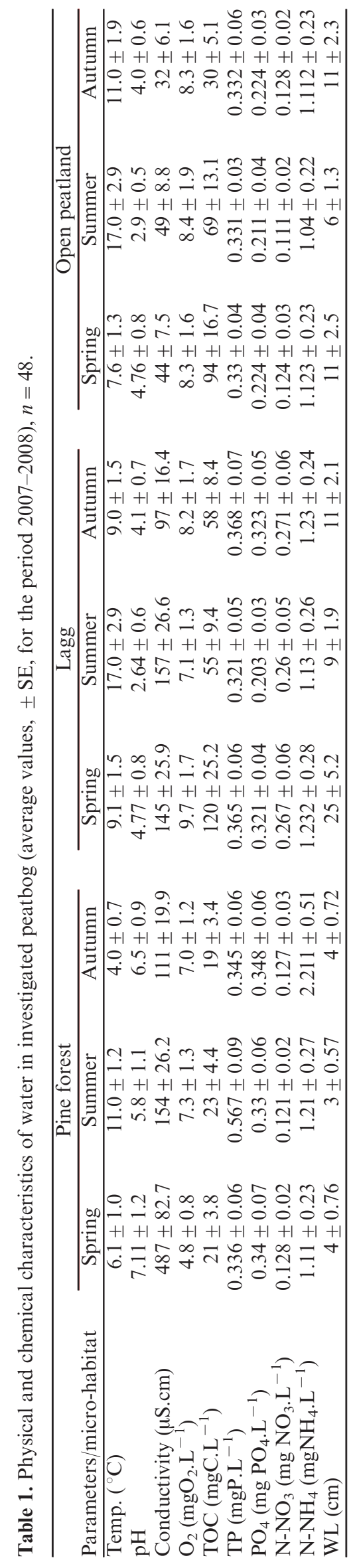

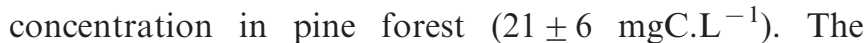
concentration of total organic carbon fluctuated between $19 \pm 3.4 \mathrm{mgC} . \mathrm{L}^{-1}$ in autumn and $120 \pm 25.2 \mathrm{mgC} . \mathrm{L}^{-1}$ in spring. Nutrients reached the highest values in the LG, and were the highest during the spring and autumn periods, and considerably lower in summer. Only PF had a higher concentration of nutrients in summer (Table 1). Only some pairs of environmental variables are strongly and significantly correlated (Table 2). Most of significant correlations were negative. The highest significant negative values of correlation coefficient were calculated for $\mathrm{pH}$ and temperature $(r=-0.77)$ and for dissolved oxygen and conductivity $(r=-0.69)$. The strongest positive correlation $(r=0.75)$ showed $\mathrm{pH}$ with $\mathrm{P}_{-} \mathrm{PO}_{4}(r=0.75)$, dissolved oxygen with TOC $(r=0.74)$, WL with TOC $(r=0.67)$ and WL with dissolved oxygen $(r=0.65)$. In general, the correlation pattern among environmental variables fits well to the horizontal distribution of studied microhabitats. In scatter plots, pine forest sites are located at the highest end of $\mathrm{pH}, \mathrm{P}_{-} \mathrm{PO}_{4}$ and conductivity gradients; lagg sites are situated on the highest end of WL gradient and peatbog sites are in the middle of the gradient.

\section{Microbial communities - general results}

A total of 44 testate amoebae taxa, 35 ciliate taxa and 75 of rotifers taxa occurred in the studied area. Species richness of protozoa and rotifers showed horizontal diversity. The highest numbers of taxa occurred in the LG (31, 13 and 45 taxa, respectively) and became much lower in the PF where merely 11 testate amoebae taxa, 5 ciliate taxa and 6 rotifers taxa were identified. The highest diversity was measured in the LG (Shannon-Wiener diversity index $H=2.2-2.5)$, and the lowest diversity was observed in the PF $(H=0.75-0.83)$ and a Gini-evenness measure of 0.60 in the PF, 0.61 in the OP and 0.78 in the LG. Microorganisms densities were shown to be significantly different with site but not with time of year (Table 3 ). The numbers of testate amoebae and ciliates varied between 1.1 and $5.3 \pm 0.6 \times 10^{2}$ cells. $\mathrm{mL}^{-1}$ and between 18 and $87 \pm 11$ cells. $\mathrm{mL}^{-1}$, respectively, with the highest mean numbers in the LG and the lowest in the PF. In all studied sites, the maximal abundance of testate amoebae was noted in spring (May) (from $2.1 \pm 0.3 \times 10^{2}$ cells. $\mathrm{mL}^{-1}$ in the PF to $5.3 \pm 1.1 \times 10^{2}$ cells. $\mathrm{mL}^{-1}$ in the $\mathrm{LG}$ ) and the lowest in autumn; however, the differences were not significant. The highest abundances of ciliate communities were noted in spring and autumn (from $46 \pm 12$ cells. $\mathrm{mL}^{-1}$ in the PF to $87 \pm 21$.cells.mL $\mathrm{m}^{-1}$ in the LG), whereas in summer we observed a remarkable decrease in ciliate abundance (from $6 \pm 2$ cells. $\mathrm{mL}^{-1}$ in the PF to $27 \pm 6$ cells. $\mathrm{mL}^{-1}$ in the $\left.\mathrm{LG}\right)$. The numbers of rotifers ranged from $111 \pm 16$ ind. $\mathrm{mL}^{-1}$ in $\mathrm{LG}$ to $65 \pm 11$ ind. $\mathrm{mL}^{-1}$ in PF. In all the examined micro-habitats, the highest abundance of these micro-organisms occurred in summer and late autumn (from $45 \pm 8$ cells. $\mathrm{mL}^{-1}$ in the PF to $111 \pm 13$ cells.mL ${ }^{-1}$ in the $\left.\mathrm{LG}\right)$, while the lowest values were recorded in late spring $\left(14 \pm 4\right.$ cells. $\left.\mathrm{mL}^{-1}\right)$. Distinct 
Table 2. Non-parametric correlation matrix of measured environment al variables in pine forest-lagg-open peatbog transect.

\begin{tabular}{|c|c|c|c|c|c|c|c|c|c|c|}
\hline & Temp. & $\mathrm{pH}$ & Conductivity & $\mathrm{O}_{2}$ & TOC & TP & $\mathrm{P}-\mathrm{PO}_{4}$ & $\mathrm{~N}-\mathrm{NO}_{3}$ & $\mathrm{~N}-\mathrm{NH}_{4}$ & WL \\
\hline Temp. & 1 & $-0.77^{* *}$ & -0.29 & 0.38 & $0.40 *$ & -0.35 & $-0.52^{* *}$ & 0.16 & -0.24 & 0.08 \\
\hline $\mathrm{pH}$ & $-0.77 * *$ & 1 & 0.33 & $-0.38 *$ & $-0.53^{* *}$ & $0.47 *$ & $0.75 * *$ & -0.22 & 0.20 & $-0.39 *$ \\
\hline Conductivity & -0.29 & 0.34 & 1 & $-0.69 * *$ & $-0.59 * *$ & 0.26 & $0.42 *$ & 0.19 & 0.34 & -0.26 \\
\hline $\mathrm{O}_{2}$ & 0.38 & $-0.38 *$ & $-0.69 * *$ & 1 & $0.74 * *$ & -0.18 & -0.21 & 0.21 & -0.19 & $0.65 * *$ \\
\hline TOC & $0.40^{*}$ & $-0.53 * *$ & $-0.59 * *$ & $0.74 * *$ & 1 & -0.27 & -0.37 & 0.37 & -0.07 & $0.67 * *$ \\
\hline $\mathrm{TP}$ & -0.35 & $0.47^{*}$ & 0.26 & -0.18 & -0.27 & 1 & 0.33 & -0.05 & $0.52 * *$ & -0.18 \\
\hline $\mathrm{P}_{-} \mathrm{PO}_{4}$ & $-0.52 * *$ & $0.75^{* *}$ & $0.42 * *$ & -0.21 & -0.37 & 0.33 & 1 & 0.27 & 0.35 & -0.14 \\
\hline $\mathrm{N}-\mathrm{NO}_{3}$ & 0.16 & -0.22 & 0.19 & 0.21 & 0.37 & -0.05 & 0.27 & 1 & 0.22 & $0.61 * *$ \\
\hline $\mathrm{N}-\mathrm{NH}_{4}$ & -0.24 & 0.20 & 0.34 & -0.19 & -0.07 & $0.52 * *$ & 0.35 & 0.22 & 1 & 0.01 \\
\hline WL & 0.08 & $-0.39 *$ & -0.26 & $0.65^{* *}$ & $0.67 * *$ & -0.18 & -0.14 & $0.61 * *$ & 0.01 & 1 \\
\hline
\end{tabular}

*Correlations significant at the level $P<0.05 ; * *$ Correlations significant at the level $P<0.01$.

Table 3. Results of main effects ANOVA on density of testate amoebae, ciliates and rotifers, testing for the effect of the time (season) and the site (horizontal distribution).

\begin{tabular}{|c|c|c|c|c|c|}
\hline & $\mathrm{df}$ & SS & MS & $F$ & $P$ \\
\hline \multicolumn{6}{|c|}{ Density of testate amoebae } \\
\hline Intercept & 1 & 90.02 & 90.02 & 122.28 & $<0.001$ \\
\hline Site $(\mathrm{Si})$ & 2 & 22.05 & 11.03 & 14.97 & $<0.001$ \\
\hline Season (Se) & 8 & 0.44 & 0.54 & 7.43 & 0.065 \\
\hline $\mathrm{Si} \times \mathrm{Se}$ & 2 & 1.18 & 7.36 & 16.37 & 0.073 \\
\hline \multicolumn{6}{|c|}{ Density of ciliates } \\
\hline Intercept & 1 & 28.22 & 28.22 & 78.16 & $<0.001$ \\
\hline Site $(\mathrm{Si})$ & 2 & 5.92 & 2.95 & 50.95 & $<0.001$ \\
\hline Season $(\mathrm{Se})$ & 8 & 0.81 & 0.11 & 8.52 & 0.090 \\
\hline $\mathrm{Si} \times \mathrm{Se}$ & 2 & 0.57 & 3.31 & 8.19 & 0.037 \\
\hline \multicolumn{6}{|c|}{ Density of rotifers } \\
\hline Intercept & 1 & 53.74 & 53.74 & 27.85 & $<0.001$ \\
\hline Site $(\mathrm{Si})$ & 2 & 17.76 & 19.32 & 5.81 & $<0.001$ \\
\hline Season $(\mathrm{Se})$ & 8 & 5.76 & 7.21 & 3.52 & 0.091 \\
\hline $\mathrm{Si} \times \mathrm{Se}$ & 2 & 3.66 & 1.53 & 4.62 & 0.087 \\
\hline
\end{tabular}

The significance of bold letters: * significant at the level $P<0.05$, **significant at the level $P<0.01$.

horizontal differences were noted in the domination structure of testate amoebae. The species distribution pattern also showed a higher variation in acid habitats (LG and OP), from wet assemblages (LG) with Hyalosphenia papilio to Assulina muscorum assemblages from drier microhabitats (PF). In the PF zone, only one species of testate amoeba typical of the zone occurred, namely Difflugia leidyi. In the LG, much more exclusive species occurred. They included: Cryptodifflugia oviformis, Difflugia globulosa, Euglypha rotunda, Euglypha strigosa, Nebela collaris, Nebela flabellulum, Placocista spinosa type, and Trigonopyxis arcula type. In the OP, no typical species were recorded. Also, the community composition of ciliates varied greatly from $\mathrm{PF}$ to $\mathrm{OP}$. The most abundant species occurring in an environment with a very low pH (LG and OP) were Colpidium colpoda and Chilodonella uncinata, while Euplotes sp. was dominant in PF. Among ciliates, exclusive (typical) species for the PF were: C. uncinata, Coleps spetai, Vorticella companula and Euplotes sp. In the LG, a significant number of typical taxa were determined, not occurring at other sites. Those were: Chlamydonella sp., Didinium sp., Lacrymaria olor, Paradileptus elephantinus, S. sensu lato, Paramecium putrinum, Aspidisca cicada, Oxytricha sp., Amphileptus claparedii, Amphileptus pleurosigma and Kahlilembus attenuotus. In the case of OP, only one exclusive species occurred, namely Cyrtohymena muscorum. The dominance structure of rotifers was very similar in all studied sites. Bdelloids were dominants and their percentage contribution to the rotifer communities varied from $60 \%$ to $80 \%$. Additionally, in LG zone Lecane lunaris accounted for over $10 \%$ of total catch. In the investigated zones, no typical rotifers species were recorded.

\section{Unconstrained ordination (DCA)}

DCA was generated for communities of testate amoebae, ciliates and rotifers and underlying environmental gradients (Figs. 2(A)-(C)). Biplots of DCA showed distribution of samples in ordination space of Axis 1 and Axis 2. Eigenvalue of ordination axes indicate that environmental gradient represented by Axis 1 the most strongly differentiated abundances of testate amoebae, ciliates and rotifers between studied habitats. Eigenvalue of Axis 1 exceeds 0.5 and amounted 0.769 for testate amoebae, 0.648 for ciliates and 0.523 for rotifers. In the biplots for ciliates, samples collected in pine forest are situated on the left side in ordination space; samples collected in lagg are situated on the right side of the diagram. In the biplots for testate 
(A)

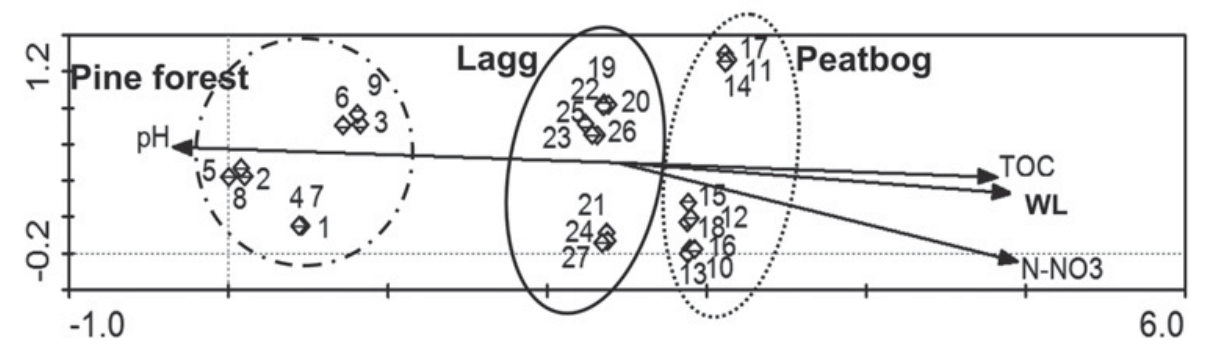

(B)

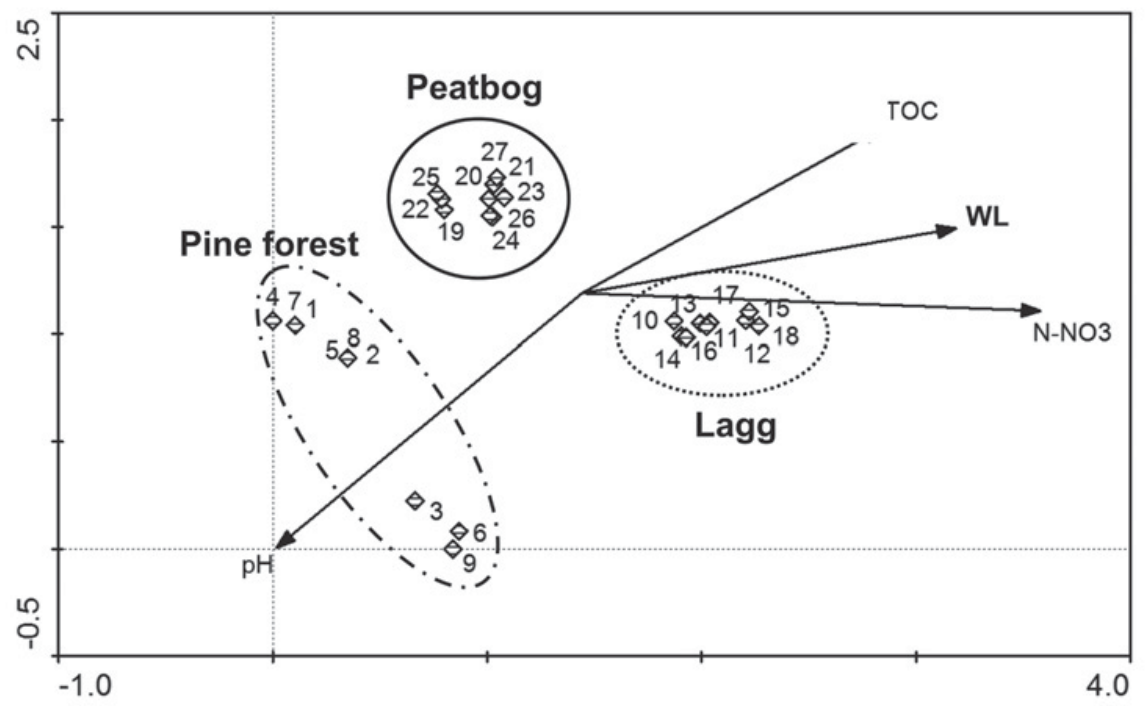

(C)

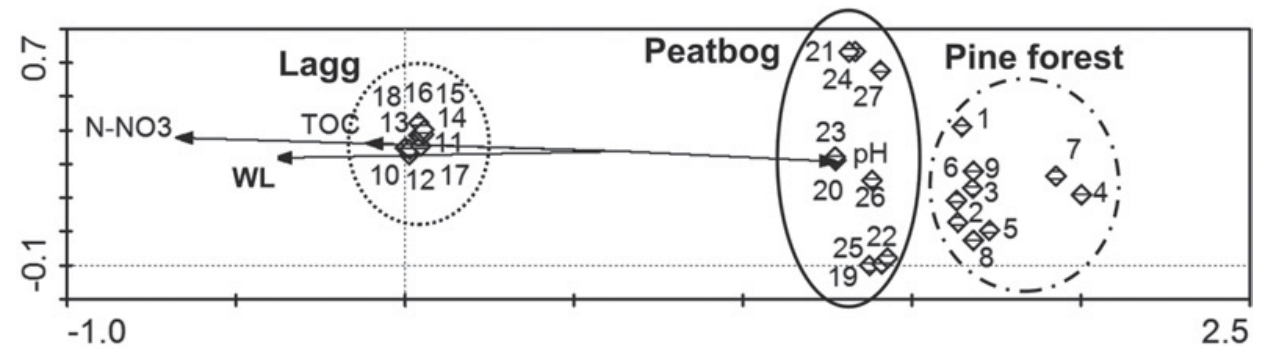

Fig. 2. Biplots of DCA for environmental variables and samples of (A) testate amoebae, (B) ciliates and (C) rotifers collected in three habitats. Samples collected in studied habitats are marked with an Arabic numeral: 1-9, Pine forest; 10-18, Lagg; 19-27, Peatbog.

amoebae, samples collected in the lagg are situated in the middle on the first ordination axis; samples collected in pine forest are situated on the left side in ordination space. The group of samples collected in peatbog lying between them. On the biplot for rotifers, the group of pine forest samples is placed on the right side of the ordination space, while samples from lagg are grouped at the left side of the diagram. The distribution of samples in ordination space led to conclude that studied habitats are distributed along the falling gradient of $\mathrm{pH}$ and rising gradient of TOC, WTD and $\mathrm{N}-\mathrm{NO}_{3}$. Thus, the rotifers and ciliates displayed the same principal gradient (PF-OP-LG) contrary to testate amoebae (PF-L-OP).

\section{Constrained ordination (CCA) - environmental gradient}

\section{Testate amoebae}

The CCA for spatial distribution of testate amoebae showed that all environmental variables together 
Table 4. Results of the forward selection of environmental variables (Monte Carlo permutation test in CCA, $P<0.05$ are statistically significant and given in bold) for three studied group of organisms: testate amoebae, ciliates and rotifers.

\begin{tabular}{|c|c|c|c|c|c|c|c|c|c|}
\hline \multirow[b]{2}{*}{ Variable } & \multicolumn{3}{|c|}{ Testate amoebae } & \multicolumn{3}{|c|}{ Ciliates } & \multicolumn{3}{|c|}{ Rotifers } \\
\hline & $\bar{\lambda}$ & $F$ & $P$ & $\lambda$ & $F$ & $P$ & $\Lambda$ & $F$ & $P$ \\
\hline Temperature & 0.02 & 0.52 & 0.806 & 0.01 & 0.60 & 0.756 & 0.01 & 1.14 & $\overline{0.362}$ \\
\hline $\mathrm{pH}$ & 0.23 & 7.24 & 0.002 & 0.03 & 1.38 & 0.208 & 0.02 & 2.95 & 0.012 \\
\hline Conductivity & 0.08 & 3.83 & 0.002 & 0.11 & 4.29 & 0.004 & 0.04 & 3.92 & 0.004 \\
\hline $\mathrm{O}_{2}$ & 0.01 & 0.36 & 0.910 & 0.01 & 0.73 & 0.636 & 0.01 & 1.31 & 0.258 \\
\hline WTD & 0.20 & 7.83 & 0.002 & 0.04 & 1.91 & 0.084 & 0.04 & 4.34 & 0.006 \\
\hline TOC & 0.015 & 0.55 & 0.776 & 0.01 & 0.38 & 0.908 & 0.01 & 1.56 & 0.152 \\
\hline $\mathrm{N}-\mathrm{NH}_{4}$ & 0.01 & 0.87 & 0.524 & 0.01 & 0.31 & 0.942 & 0.01 & 0.66 & 0.732 \\
\hline $\mathrm{N}-\mathrm{NO}_{3}$ & 0.02 & 0.39 & 0.898 & 0.21 & 7.33 & 0.002 & 0.24 & 18.56 & 0.002 \\
\hline TP & 0.08 & 3.73 & 0.004 & 0.09 & 3.98 & 0.002 & 0.02 & 2.46 & 0.016 \\
\hline $\mathrm{P}-\mathrm{PO}_{4}$ & 0.03 & 1.44 & 0.192 & 0.05 & 2.02 & 0.064 & 0.05 & 3.65 & 0.006 \\
\hline
\end{tabular}

explained $65.3 \%$ of the total variance. However, Monte Carlo permutation test $(P<0.05)$ showed the significance of WTD, conductivity, TP and $\mathrm{pH}$ in explaining the variability of testate amoebae in all habitats (Table 4). At the CCA biplots (Fig. 3(A)) samples are divided into three groups (habitats): pine forest, lagg and peatland. Axis 1 separated peatbog samples from lagg and pine forest. The species collected in pine forest (Euglypha sp., Diffugia leidyi, N. flabellulum and N. collaris) correspond with rising gradient of $\mathrm{pH}, \mathrm{TP}$ and conductivity. Large group of species of testate amoebae (such as Arcella catinus, Hyalosphenia elegans, Nebela bohemica, N. carinata, Nebela griseola, Nebela militaris, D. globulosa and E. strigosa) are observed in habitats of higher water level (WTD) and correspond with lagg habitat. In the ordination biplot (Fig. 3(A)) species of testate amoebae (Heleoptera petricola, Heleoptera sphagnii, Heleoptera rosea, Corythion dubium, Corythion-Trinema type, Cyclopyxis arcelloides, Euglypha ciliate and Euglypha compressa) showed positive relation with rising gradient of TOC, $\mathrm{O}_{2}$ and temperature and may correspond with peatland habitat (Fig. 3(B)).

\section{Ciliates}

The CCA showed that all environmental variables explained $60.8 \%$ of the total variance of ciliates in studied habitats. Only three variables $\left(\mathrm{N}-\mathrm{NO}_{3}\right.$, conductivity and TP) showed significant importance in Monte Carlo permutation test at $P<0.05$ (Table 4). Axis 1 correlate mostly with $\mathrm{N}_{-} \mathrm{NO}_{3}$ and correspond with the group of species (A. claparedii, A. pleurosigma, Codonella cratera, Paramecium sp., A. cicada and Didinium sp.) commonly observed in lagg habitat. Axis 2 is mostly correlated with conductivity and TP. These variables may influence the presence of ciliate species: C. uncinata, $V$. companula, Euplotes sp. and correspond with pine forest habitat (Figs. 4(A) and (B)).

\section{Rotifers}

All environmental variables explained $78.4 \%$ of the total variability. Monte Carlo permutation test at $P<0.05$ showed the significance of six variables: $\mathrm{pH}$, conductivity, WTD, TP, $\mathrm{P}_{-} \mathrm{PO}_{4}$ and $\mathrm{N}-\mathrm{NO}_{3}$ in explaining the variability of rotifers in three studied habitats (Table 4). On the CCA biplots rotifers communities of studied habitats and species are visibly separated (Figs. 5(A) and (B)). Axis 1 correlates mostly with $\mathrm{N}_{-} \mathrm{NO}_{3}$ and WTD. These environmental variables affect the abundance of rotifer species, Lepadella sp., Keratella serrulata, Colurella hindenburgi, Collotheca wiszniewski and correspond with lagg habitat. Axis 2 is mostly correlated with conductivity, $\mathrm{P}-\mathrm{PO}_{4}, \mathrm{TP}$ and $\mathrm{pH}$. Two variables TP and $\mathrm{pH}$ showed the relation with rotifers species, Lecane intrasinuata, Lecane flexilis, Lecane scutata and Rotaria sordida, and may correspond with forest habitat.

\section{Seasonal variability in testate amoebae, ciliates and rotifers data}

Analysis of testate amoebae, ciliates and rotifers data and environmental variables in all the studied habitats (CCA) revealed seasonal changes in species composition and environmental conditions (Figs. 6-8(A) and (B)). For pine forest habitat, the eigenvalue of first axis amounted 0.157 and for the second axis -0.103 . These two axes captured $89.3 \%$ of the total variation of species data. The highest significant values of regression coefficients $(P>0.05)$ showed conductivity and $\mathrm{N}-\mathrm{NO}_{3}$ along Axis 1 and $\mathrm{pH}$ and WL along Axis 2. Samples collected in studied seasons are clustered in three groups. Samples in April, July and October are clustered together; samples in June are grouped with samples in September and samples collected in May, August and November are clustered together (Fig. 6(A)). Ciliates, Holosticha pullaster, V. companula and Podophyra sp. were characteristic species in April, July and October (Fig. 6(B)). Testate amoebae, $H$. petricola, $H$. rosea and $H$. sphagnii and two ciliates species, Coleps hirtus and C. spetai were characteristic species in September. Rotifer species, Lepadella patella and ciliate Strombidium viride were characteristic species for samples collected in May and November.

For lagg habitat, first and second axis explained 77.5\% of total variability of species data. Eigenvalue of Axis 1 
(A)

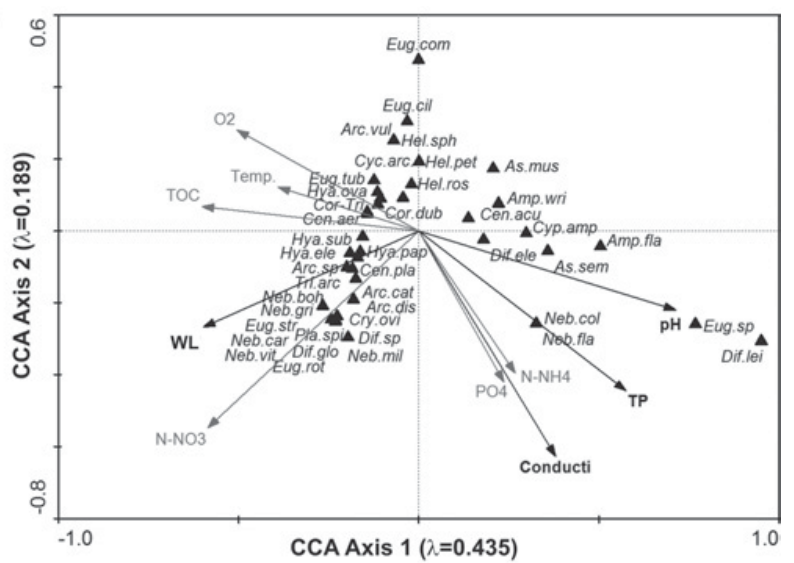

(B)

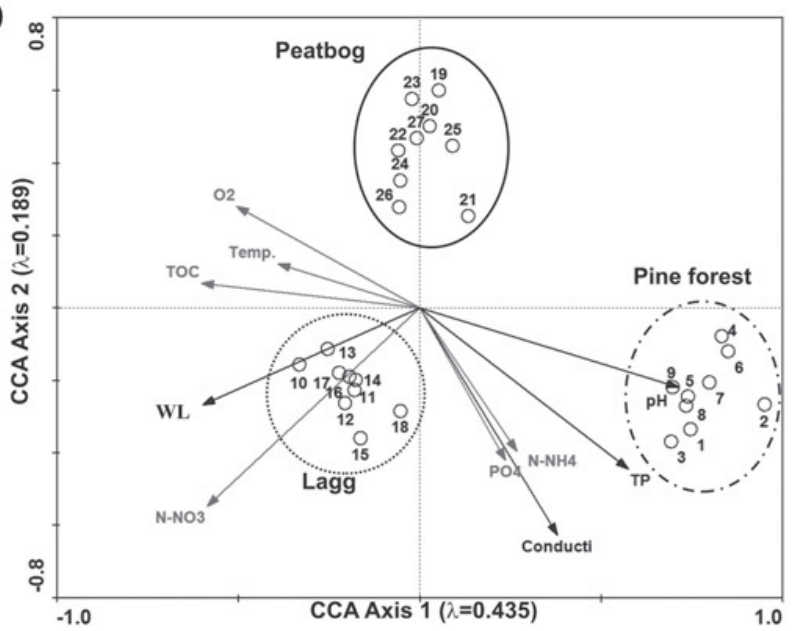

Fig. 3. Biplots of CCA of testate amoebae (A) species, (B) samples. Arrows marked as bold indicate significant parameters in Monte Carlo permutation test at $P<0.05$. Samples collected in studied habitats are marked with an Arabic numeral: 1-9, Pine forest; 10-18, Lagg; 19-27, Peatbog. Species codes: Amp.fla, Amphitrema flavum; Amp.wri, Amphitrema wrightianum; Arc.cat, Arcella catinus type; Arc.dis, Arcella disoides type, Arc. sp, Arcella sp.; Arc. vul, Arcella vulgaris; Ass. mus, Assulina muscorum; Ass. sem, Assulina seminulum; Cen.acu, Centropyxis aculeata type; Cen.aer, Centropyxis aerophila; Cen.pla, Centropyxis platystoma type; Cor.dub, Corythion dubiom; Cor.Tri, Corythion-Trinema type; Cry.ovi, Cryptodifflugia oviformis; Cyc.arc, Cyclopyxis arcelloides type; Cyp.amp, Cyphoderia ampulla; Dif.ele, Difflugia elegants; Dif.glo, Difflugia globulosa; Dif.lei, Difflugia leidyi; Dif.sp, Difflugia sp.; Eug.cil, Euglypha ciliata; Eug.com, Euglypha compressa; Eug.rot, Euglypha rotunda type; Eug.sp, Euglypha sp.; Eug.str, Euglypha strigosa; Eug.tub, Euglypha tuberculata type; Hel.pet, Heleoptera petricola; Hel.ros, Heleoptera rosea; Hel.sph, Heleoptera sphagnii; Hya.ele, Hyalosphenia elegans; Hya.ova, Hyalosphenia ovalis; Hya.pap, Hyalosphenia papilio; Hya.sub, Hyalosphenia subflava; Neb.boh, Nebela bohemica; Neb.car, Nebela carinata; Neb.col, Nebela collaris; Neb.fla, Nebela flabellulum; Neb.gri, Nebela griseola type; Neb.mil, Nebela militaris; Neb.vit, Nebela vitraea type; Pla.spi, Placocista spinosa type; Tri.arc, Trigonopyxis arcula type.

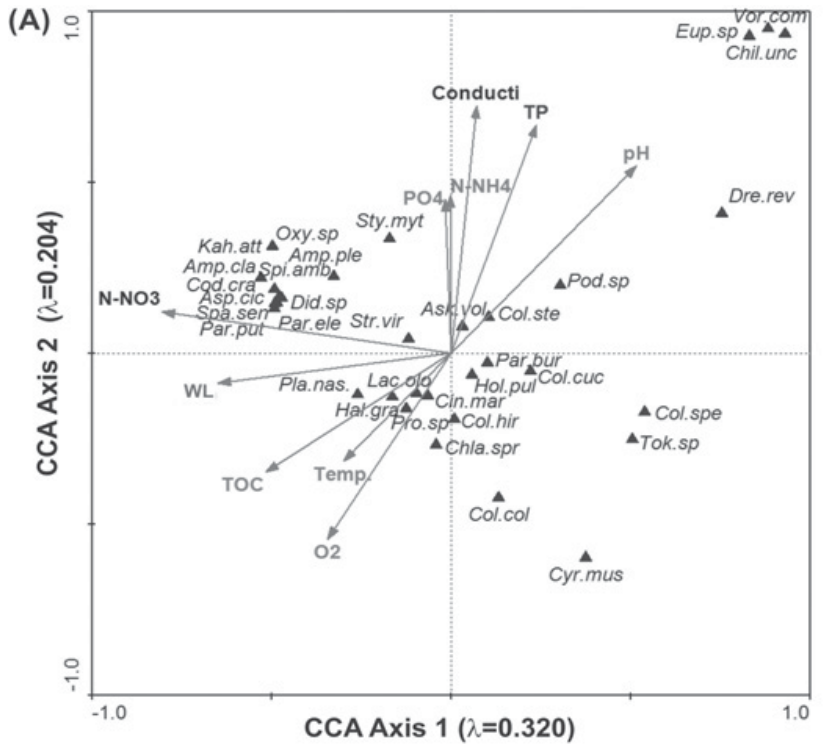

(B)

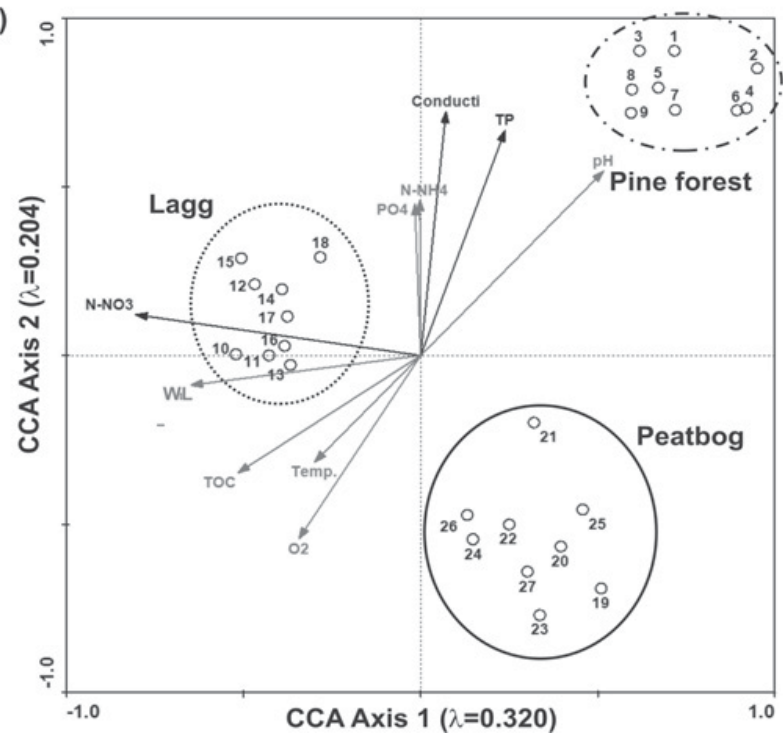

Fig. 4. Biplots of CCA of ciliates (A) species and (B) samples. Arrows marked as bolded indicate significant parameters in Monte Carlo permutation test at $P<0.05$. Samples collected in studied habitats are marked with an Arabic numeral: 1-9, Pine forest; 10-18, Lagg; 19-27, Peatbog. Species codes: Chil.unc, Chilodonella uncinata; Chla.spr, Chlamydonella-spr; Col.ste, Colpoda steinii; Col.cuc, Colpoda cucullus; Col.col, Colpidium colpoda; Ask.vol, Askenasia volvox; Did.sp, Didinium sp.; Lac.olo, Lacrymaria olor; Par.ele, Paradileptus elephantinus; Pla.nas, Plagiopyla nasuta; Spa.sen, Spathidium sensu lato; Spi-amb, Spirostomum ambigum; Par.bur, Paramecium bursaria; Par.put, Paramecium putrinum; Cin.mar, Cinetochilum margaritaceum; Asp.cic, Aspidisca cicada; Eup.sp, Euplotes sp.; Hol.pul, Holosticha pullaster; Oxy.sp, Oxytricha sp.; Sty.myt, Stylonychia mytilus-Komplex; Cod.cra, Codonella cratera; Hal.gra, Halteria gradinella; Str.vir, Strombidium viride; Vor.com, Vorticella companula; Amp.cla, Amphileptus claparedii; Amp.ple, Amphileptus pleurosigma; Col.hia, Coleps hirtus; Col.spe, Coleps spetai; Pro.sp, Prorodon sp.; Dre.rez, Drepanomonas rezoluta; Tok.sp, Tokophrya sp.; Pod.sp, Podophrya sp.; Cry.mus, Cyrtohymena muscorum; Kah.att, Kahlilembus attenuatus. 
(A)

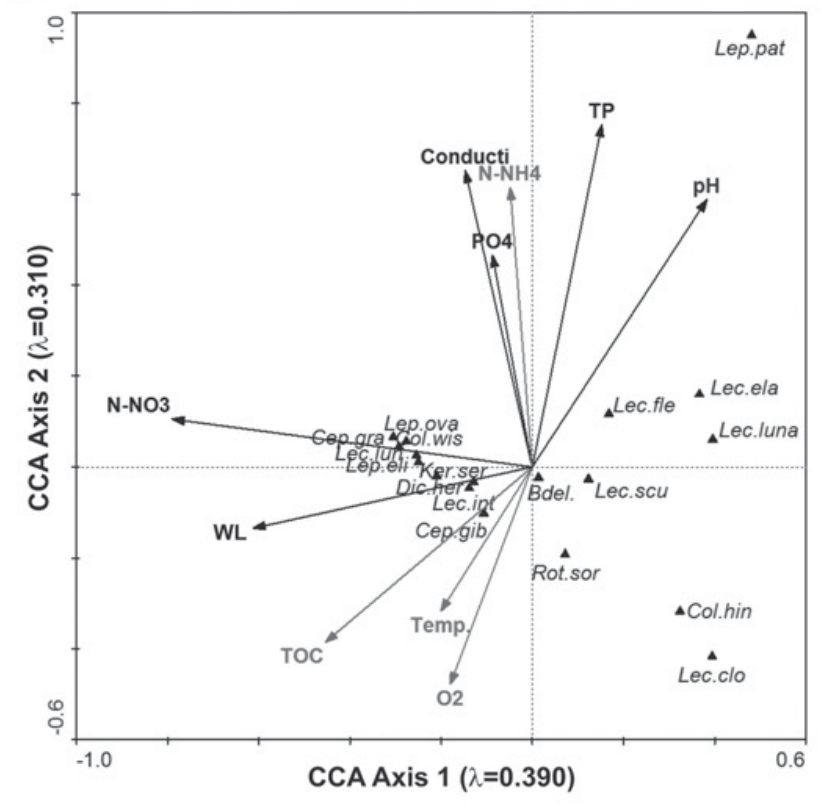

(B)

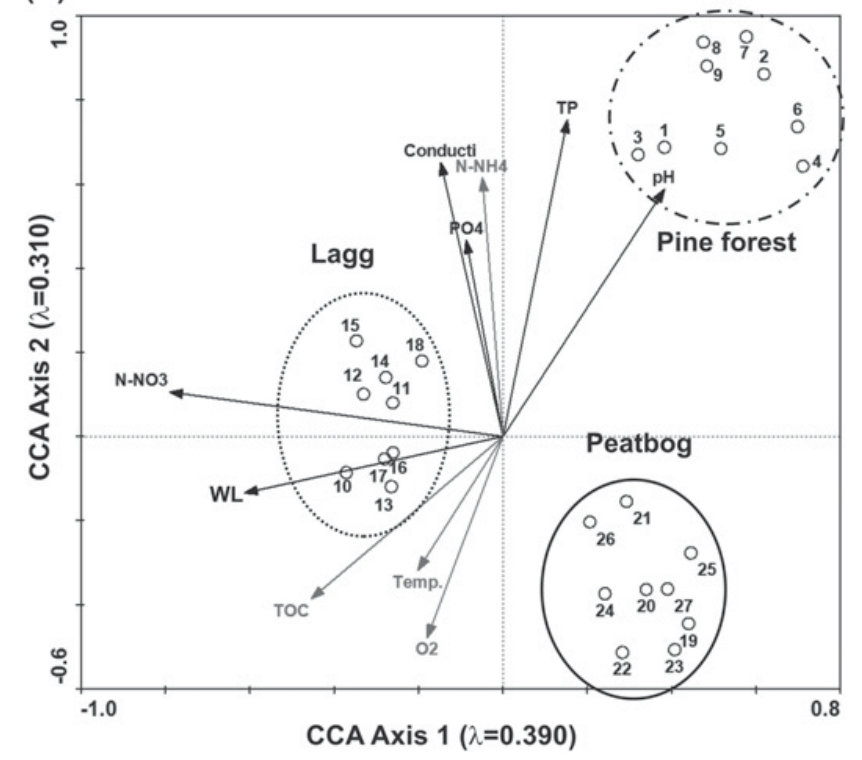

Fig. 5. Biplots of CCA of rotifers (A) species and (B) samples. Arrows marked bold indicate significant parameters in Monte Carlo permutation test at $P<0.05$. Samples collected in studied habitats are marked with an Arabic numeral: 1-9, Pine forest; 10-18, Lagg; 19-27, Peatbog. Species codes: Bdel, Bdelloida; Cep.gib, Cephalodella gibba; Cep.gibb, Cephalodella gibboides; Cep.gra, Cephalodella gracilis; Col.wis, Collotheca wiszniewski; Col.hin, Colurella hindenburgi; Dic.her, Dicranophorus herkules; Ker.ser, Keratella serrulata; Lec.clo, Lecane closterocerca; Lec.ela, Lecane elasma; Lec.fle, Lecane flexilis; Lec.int, Lecane intrasinuata; Lec.lun, Lecane luna; Lec.luna, Lecane lunaris; Lec.scu, Lecane scutata; Lep.eli, Lepadella eliptica; Lep.ova, Lepadella ovalis; Lep.pat, Lepadella patella; Rot.sor, Rotaria sordida.
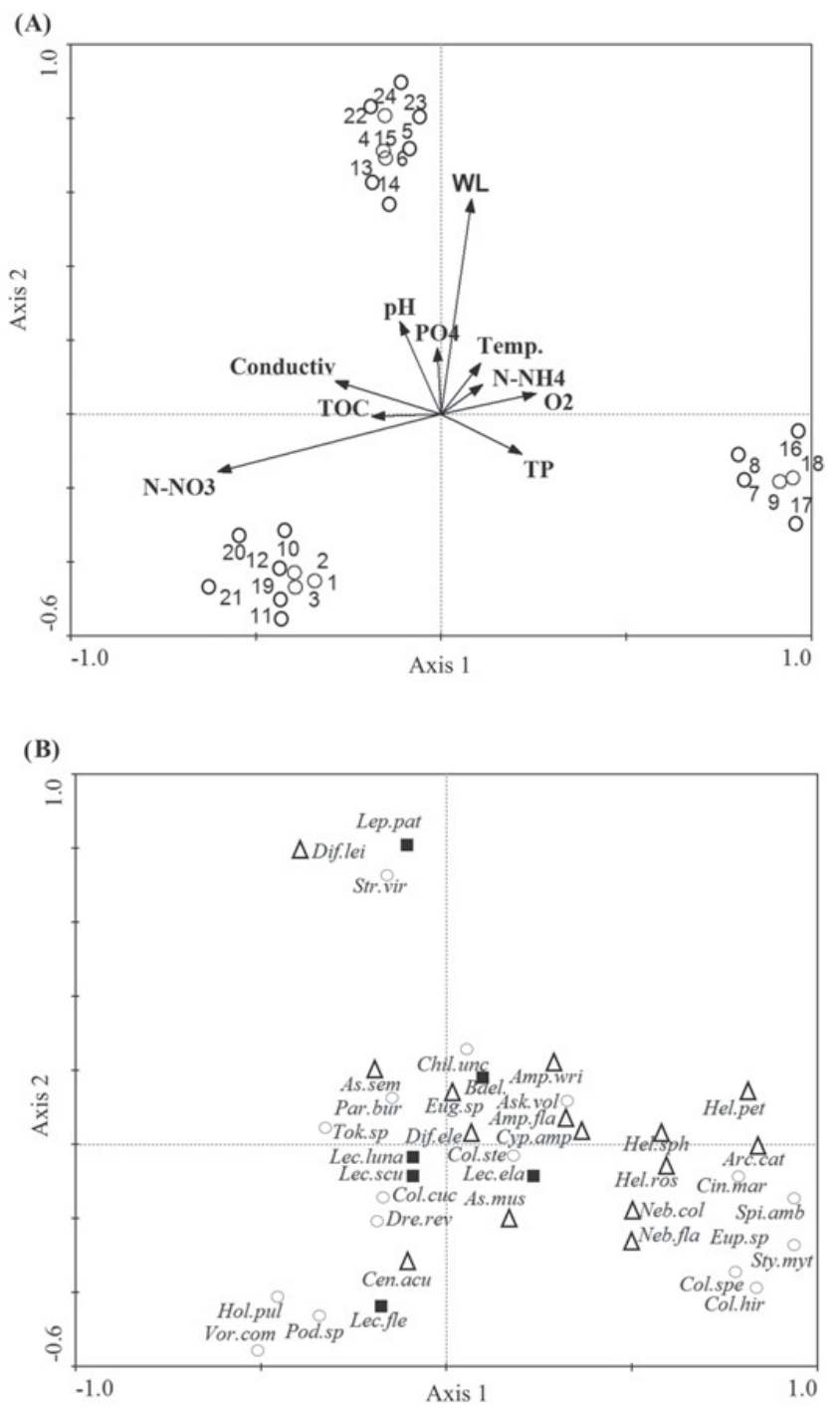

Fig. 6. Biplots of CCA of testate amoebae, ciliates and rotifers data in pine forest. (A) Seasons and environmental variables plot; (B) species and environmental variables plot. Environmental variables are the same as in part (A) but are not shown for clarity. Empty circles, ciliates; empty triangle, testate amoebae; filled square, rotifers. Samples collected in studied months are marked with an Arabic numeral: 1-3 April; 4-6 May; 7-9 June; 10-12 July; 13-15 August; 16-18 September; 19-21 October; 22-24 November. Abbreviations of species names are the same as in Figures 3-5.

amounted to 0.063 and for Axis 2, 0.035. Temperature and $\mathrm{N}-\mathrm{NH}_{4}$ showed the highest significant values of regression coefficients along Axis 1 . Along Axis 2 the highest values of regression coefficient showed TP and $\mathrm{N}-\mathrm{NH}_{4}$. In the ordination diagram, four groups of samples can be observed. Samples collected in May and August are clustered together. Samples in April are combined with July and October; samples in June and September are clustered together; samples in November are placed separately (Fig. 7(A)). Testate amoebae, E. rotunda and E. compressa are characteristic species for samples collected in May and 

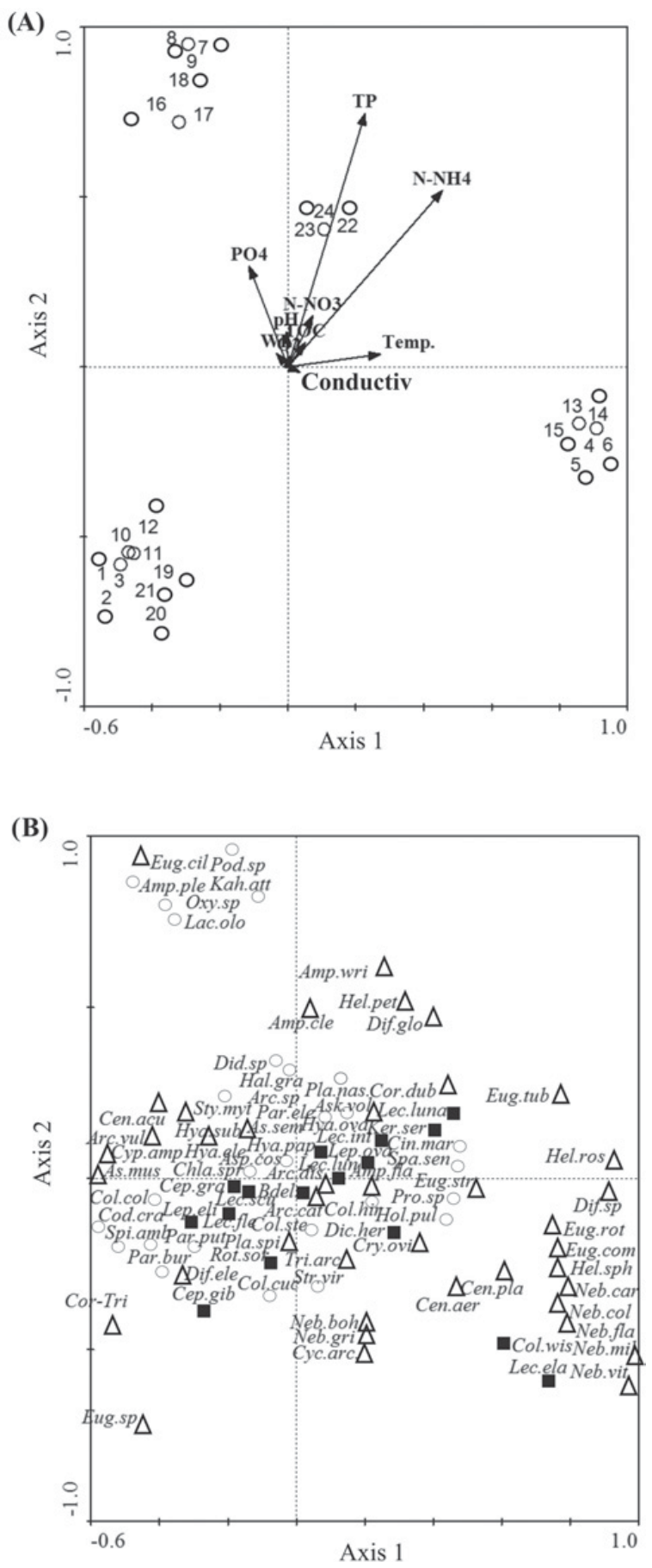

Fig. 7. Biplots of CCA of testate amoebae, ciliates and rotifers data in lagg. (A) Seasons and environmental variables plot; (B) species and environmental variables plot. Environmental variables are the same as in (A) but are not shown for clarity. Empty circles, ciliates; empty triangle, testate amoebae; filled square, rotifers. Samples collected in studied months are marked with an Arabic numeral: 1-3 April; 4-6 May; 7-9 June; 10-12 July; 13-15 August; 16-18 September; 19-21 October; 22-24 November. Abbreviations of species names are the same as in Figures 3-5.
August; Euglypha sp. and Corythion-Trienema type are typical for April and October samples. Testate amoebae Amphitrema wrightianum and $H$. petricola and ciliate A. claparedii are characteristic species for November samples. Ciliates, A. pleurosigma, Oxytricha sp. and Podophyra sp. are characteristic species for samples collected in June and September (Fig. 7(B)).

For open peatbog habitat, first and second ordination axis explained $84.2 \%$ of total species variability. Eigenvalue of Axis 1 amounted to 0.077 and Axis 2, 0.030 . Regression coefficients showed the highest significant values for TOC and $\mathrm{N}^{-\mathrm{NH}_{4}}$ along Axis 1 and for TP and $\mathrm{O}_{2}$ along Axis 2. On the ordination plot, similarly to lagg habitat, samples collected in studied seasons are divided into four groups. Samples in April and July are clustered together; sample collected in May are grouped with samples in August; samples in June, September and November are clustered together and samples in October are put separately (Fig. 8(A)). Testate amoebae, H. rosea and $H$. sphagnii were characteristic for October samples. Rotifers, K. serrulata, Lecane closterocerca, L. luna and Lepadella eliptica were typical for samples collected in April and July. Testate amoebae, Corythion-Trinema type and Hyalosphenia subflava, ciliate L. olor and rotifer species $C$. hindenburgi were characteristic species for June (Fig. 8(B)).

The CCA on individual environmental variables revealed that the proportion of testate amoebae, ciliates and rotifers data explained by each of variable and the significance varied strongly among variables and among three studied habitats (Table 5). In the separate CCAs on "pine forest", "lagg" and "open peatbog" samples, N$\mathrm{NH}_{4}, \mathrm{~N}_{-} \mathrm{NO}_{3}$ and $\mathrm{WL}$ were significant. The highest proportion of variance in pine forest habitat explained $\mathrm{pH}$, TOC and $\mathrm{N}-\mathrm{NH}_{4}$; in lagg, temperature and TP and in open peatbog - conductivity and $\mathrm{N}-\mathrm{NO}_{3}$.

\section{Discussion}

\section{Physical and chemical parameters}

Physical and chemical water parameters showed high differentiation in investigated macro-habitats. The waters of the forest catchment area were distinguished by much higher $\mathrm{pH}$ values than those of the lagg and open peatbog zones. The results are significantly different than those presented by Kruk (2003), dealing with studies on a similar horizontal transect of a raised bog. The studies concerned the agricultural catchmentlagg-open bog transect. The author determined significant similarity of reaction of the waters of the agricultural catchment and the lagg area. Probably transported ions, namely $\mathrm{Ca}^{2+}$ from the agriculture catchment are subjected to changes of water parameters. However, the periodical inflow of water from agriculture catchment alkalize this zone and, as a result, threaten the ecological system of bog, what is realized by increasing lagg area at the cost of bog area and by the decay of ombrotrophic 
(A)

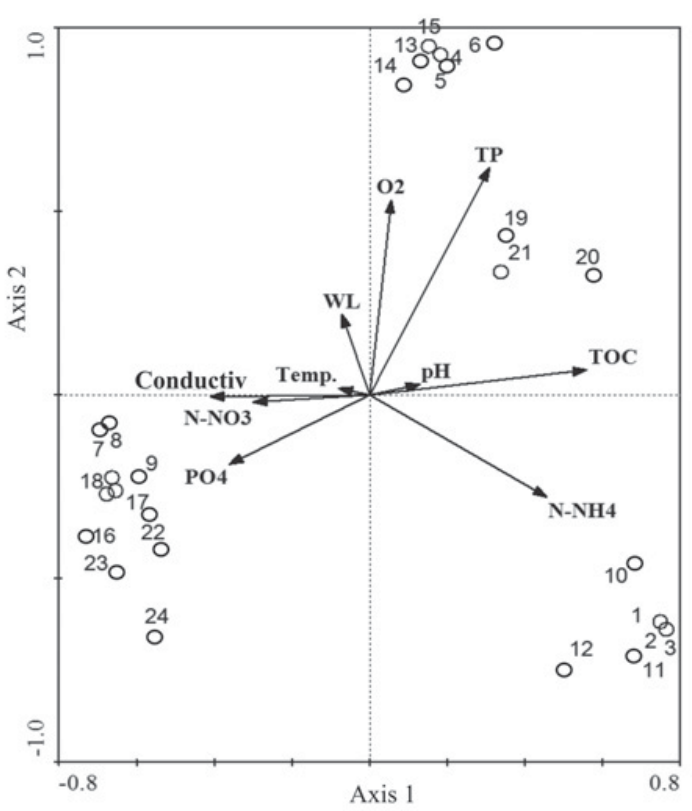

(B)

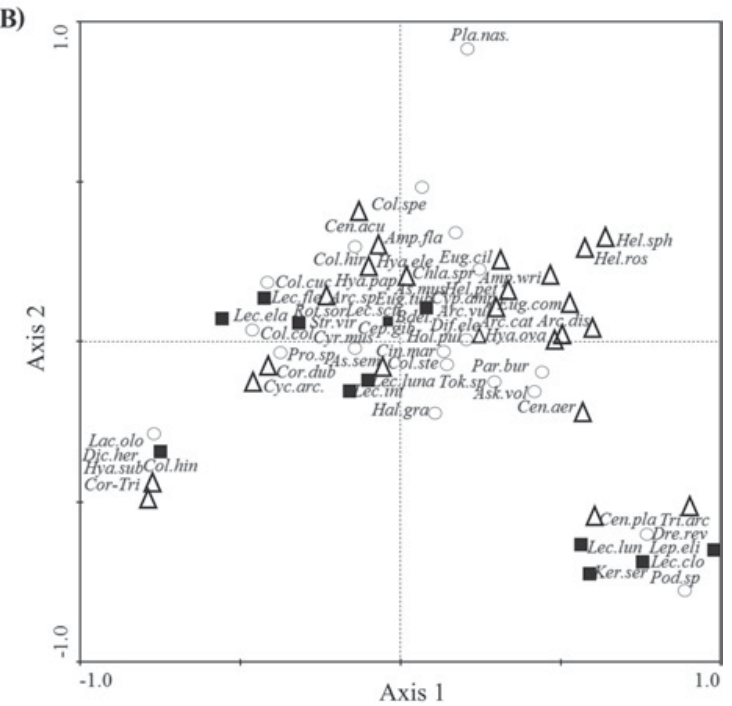

Fig. 8. Biplots of CCA of testate amoebae, ciliates and rotifers data in open peatbog. (A) Seasons and environmental variables plot; (B) species and environmental variables plot. Environmental variables are the same as in (A) but are not shown for clarity. Empty circles, ciliates; empty triangle, testate amoebae; filled square, rotifers. Samples collected in studied months are marked with an Arabic numeral: 1-3 April; 4-6 May; 7-9 June; 10-12 July; 13-15 August; 16-18 September; 19-21 October; 22-24 November. Abbreviations of species names are the same as in Figures 3-5.

flora components (Kruk, 2003). The present study reveals high differentiation between the reaction values of waters from the forest catchment and lagg (the lagg waters are more acidic). Such a situation probably results from among others occurrence of humic acids in the water, developed in the process of oxygenation of organic detritus (Górniak et al., 1999). Dead Sphagnum biomass in the lagg environment can contribute to deposition of large amounts of humus throughout the year, and active acidification of waters. Concentration of nutrients was varied at individual sites, whereas it reached values typical of ombrotrophic peatlands, recorded among others in Europe (Jauhiainen, 2002; Mieczan, 2009a, 2009b). Concentration of nutrients in the horizontal transect showed their reduction towards the open peatbog. Their sources (especially the source of phosphates) are probably waters from the forest catchment. Additionally, it could be suggested that lower water level and higher decomposition are connected with alkalization and eutrophization of lagg waters. They may partly be supplied to the peatbog, and the lagg zone may partly seize them, fulfilling the function of a "biofilter". The concentrations of phosphates were higher in lagg similar to pine forest and contrary to open peatbog. Similar patterns were also observed within the raised bog located in the Mazurian Lakeland (Kruk, 2003).

\section{Microbial communities}

So far, comparative data concerning distribution of protozoa and rotifers in the horizontal transect (forest catchment-lagg-open peatbog) are very scarce. This study suggests significant relationships between the species richness of protozoa and metazoa and the type of a habitat. In the lagg zone, dominated by S. angustifolium, a significantly higher number of species were recorded in comparison with the remaining zones analysed. Analysis of testate amoebae, ciliates and rotifers data and environmental variables in all of the studied habitats revealed seasonal changes in species composition and environmental conditions. Bobrov et al. (1999) observed a clear increase in species diversity in wet microhabitats. Favourable hydrological conditions also occurred in the lagg zone. The species diversity of testate amoebae was similar to that recorded in other regions of Europe (Jauhiainen, 2002; Lamentowicz et al., 2010; Jassey et al., 2011). Such a similarity is not surprising in view of the largely cosmopolitan character of testate amoebae. The species diversity, however, showed clear differentiation between individual zones. Particularly low species diversity of testate amoebae in the pine forest zone probably results from low humidity of the microhabitat. The number of species increased with decreasing $\mathrm{pH}$ and rising humidity of the habitats. Testate amoebae also need to find the required material to build their test, and this requirement may be another constraint that determines their distribution (Meisterfeld, 1977). In Greek peatbogs, Payne and Mitchell (2007) emphasized the significant influence of the level of the water table and $\mathrm{pH}$ on occurrence of the testate amoebae. Such a relation also exists in the peatbog studied. In each of the study periods, the highest water level was determined in the lagg zone, with simultaneous highest numbers of protozoa. The abundance of testate amoebae was seasonally variable in all the studied sites; however, the difference was not significant. 
Table 5. Summary of CCA on testate amoebae, ciliates, rotifers and environmental variables from pine forest-lagg-open peatbog transect and significance of individual variables taken alone.

\begin{tabular}{|c|c|c|c|c|c|c|c|c|}
\hline \multirow[b]{2}{*}{ Variable } & \multicolumn{2}{|c|}{ Overall CCA } & \multicolumn{2}{|c|}{ Pine forest } & \multicolumn{2}{|c|}{ Lagg } & \multicolumn{2}{|c|}{ Open peatbog } \\
\hline & $\%$ & $P$ value & $\%$ & $P$ value & $\%$ & $P$ value & $\%$ & $P$ value \\
\hline Temp. & 25.4 & 0.19 & 10.6 & 0.49 & 25.7 & 0.72 & 7.8 & 0.21 \\
\hline $\mathrm{pH}$ & 4.7 & 0.31 & 11.1 & 0.34 & 9.9 & 0.16 & 12.7 & 0.07 \\
\hline Conductivity & 1.4 & 0.28 & 2.8 & 0.55 & 6.6 & 0.33 & 40.1 & 0.54 \\
\hline $\mathrm{O}_{2}$ & 2.7 & 0.10 & 2.6 & 0.02 & 5.7 & 0.31 & 0.5 & 0.13 \\
\hline TOC & 4.9 & 0.15 & 18.7 & 0.19 & 6.8 & 0.25 & 5.5 & 0.66 \\
\hline TP & 2.5 & 0.16 & 2.2 & 0.65 & 21.4 & 0.32 & 3.1 & 0.58 \\
\hline $\mathrm{PO}_{4}$ & 0.2 & 0.07 & 6.3 & 0.34 & 10.7 & 0.26 & 3.6 & 0.78 \\
\hline $\mathrm{N}-\mathrm{NO}_{3}$ & 7.6 & 0.14 & 10.6 & 0.01 & 6.8 & 0.01 & 29.5 & 0.01 \\
\hline $\mathrm{N}-\mathrm{NH}_{4}$ & 0.1 & 0.03 & 11.1 & 0.01 & 4.3 & 0.01 & 4.5 & 0.01 \\
\hline WL & 6.3 & 0.06 & 8.2 & 0.01 & 14.9 & 0.01 & 6.9 & 0.01 \\
\hline
\end{tabular}

Likewise the study carried out by Warner et al. (2007) determined a seasonal change in testate amoebae assemblages. In the present study, the highest abundance occurred during spring and could have resulted from higher water level and acidity. During the spring period, those characteristic species of environments with considerable moisture were recorded in high numbers (e.g., H. elegans, H. sphagnii and Arcella vulgaris). Spring or summer peaks have also been noted by Heal (1964) and Gilbert et al. (1998). Testate amoebae occurring in a given peatbog complex were mainly represented by: Arcellidae and Hyalosphenidae. Among species belonging to genus Arcella, the highest numbers were reached by Arcella discoides, and among genus Hyalosphenia, three species predominated: $H$. elegans, Hyalosphenia ovalis and $H$. papilio. The taxa are described as the so-called $\alpha$-hydrophiles, and predominate in habitats with significant humidity. A similar dominance structure was determined among others in peatlands of northern Russia (Bobrov et al., 1999). In the forest catchment zone, only one species of testate amoeba typical of the zone occurred, namely $D$. leidyi. In the lagg zone, much more exclusive species occurred. They included: $C$. oviformis, D. globulosa, Difflugia sp., E. rotunda, E. strigosa, $N$. collaris, $N$. flabellulum, $P$. spinosa and $T$. arcula. In the open peatbog zone, no typical species were recorded. The structure is characteristic for habitats of the type, and was earlier described by other researchers (Lamentowicz and Mitchell, 2005; Mieczan, 2009b).

The number of identified taxa and abundance of ciliates is comparable with other studies examining the surface water of peatbogs (Grolière, 1975, 1977, 1978; Mieczan, 2009a). The similarities between these surveys are not surprising, and support previous studies in illustrating the cosmopolitan distribution of many ciliates (Finlay, 1980). The three investigated sites had different ciliate assemblages with respect to species composition, total numbers, as well as distribution of particular dominating species. Similar to species richness, also numbers of ciliates were significantly higher in the lagg zone in comparison with other zones. The differentiation probably resulted from fertility of the microhabitat (contents of nutrients). Their concentrations indirectly condition occurrence of protozoa by affecting abundance of bacteria. Bacteria constitute the main source of alimentation for ciliates in various types of hydrogenic ecosystems (Mieczan, 2007, 2009a). Maximum densities of ciliates have often been observed during mid or late spring (Mieczan, 2007). In addition to high late-spring densities, the concentrations of ciliates reached a peak in autumn. Spring and autumn peaks of ciliates coincided with the higher concentrations of total organic carbon and/or nutrients in three studied macro-habitats. In early spring and autumn, the sites were characterized by the presence of a considerable amount of decaying plant materials. Such a type of environment could enhance a massive development of bacteria and therefore bacterivorous ciliates. The highest contribution among ciliates was reached by species belonging to Colpodea, with Colpoda steinii occurring in the highest numbers. The species was observed both in mosses and in surface layers of soils (Foissner and Berger, 1996; Bamforth et al., 2001). According to some authors (Foissner et al., 1994), the species usually occurs in oligo- and beta-mesosaprobe environments. Grolière $(1975,1977,1978)$ recorded the species on Sphagnum peatlands in France. Strüdel-Kypke and Schönborn (1999) observed its occurrence on glass plates exposed in dystrophic lakes in Germany. Among ciliates, exclusive (typical) species for the pine forest were: C. uncinata, C. spetai, V. companula and Euplotes sp. In the lagg zone, a significant number of typical taxa were determined, not occurring at other sites. Those were: Chlamydonella sp., Didinium sp., L. olor, P. elephantinus, Spathidium sensu lato, P. putrinum, A. cicada, Oxytricha sp., A. cleparedii, A. pleurosigma and $K$. attenuotus. In the case of the open peatland, only one exclusive species occurred, namely C. muscorum.

The species diversity and abundance of rotifers varied greatly from pine forest to open peatbog zone. This trend is probably related to differences in moisture content and $\mathrm{pH}$, both of which are lower in open peatbog than lagg. The present study has revealed a remarkable relationship between the abundance of rotifers and ciliates. The decrease in abundance of ciliates in summer coincided with the peak of rotifer abundance. This may be due to both thermal preferences and conditions for feeding. 
Among rotifers, in all the studied habitats, bdelloids were the most abundant. Most of the dominant species of rotifers were characterized by a broad range of $\mathrm{pH}$ tolerance. L. lunaris is known to be tolerant to a broad range of $\mathrm{pH}$ (Pejler and Berzins, 1993). Also L. intrasinua$t a$ is a characteristic species for peatlands, especially for microsites dominated by Sphagnum mosses (Bateman and Davis, 1980; Warner and Asada, 2006). Their dominance in aquatic ecosystems with a low $\mathrm{pH}$ has been reported by many researchers (Bateman and Davis, 1980; Petz, 1987; Warner and Asada, 2006). Sphagnum acidifies its habitat, so rotifer diversity is limited to the species that tolerate a low pH (Berzins and Pejler, 1987). Similar relationships were observed in different types of peatlands in eastern Poland (Bielańska-Grajner et al., 2011). Such a high tolerance may be associated with their mode of reproduction, i.e., obligatory parthenogenesis (Berzins and Pejler, 1987), and - consequently - with its colonization strategy (Pejler and Berzins, 1993). Some authors suggest that the level of total dissolved carbon may be a significant factor affecting animal communities in peatbogs (Mieczan, 2009a). It also seems that concentrations of nutrients may significantly influence the communities of rotifers. In this study, we detected a significant positive correlation between rotifers abundance and the concentration of phosphates and nitrates. It seems that nutrients have an indirect influence on the abundance of protozoans and small metazoa, through the control of food abundance (mainly bacteria, fungi, or other protists). Data on relations between testate amoebae, ciliate and rotifer communities in Sphagnum peatlands and water chemistry parameters are, however, still insufficient.

The issues referring to mutual relations between the open peatland and its rim zone, i.e., lagg, constitute a marginal subject in "peatbogs literature". However, the role of the lagg zone in transformations of Sphagnum peatbogs deserves special attention due to its simultaneous buffer and transfer functions. The lagg zone of a raised bog can fulfil the function of an ecotone zone, distinguished by a significant increase in biodiversity, abundance and species specificity of micro-organisms. It can also be a place of very efficient matter and energy flow in a peatbog ecosystem.

\section{References}

Augustin H., Foissner W. and Adam H., 1984. An improved pyridinated silver carbonate method which need few specimens and yields permanent slides of impregnation ciliates (Protozoa, Ciliophora). Mikroskopie, 41, 134-137.

Bałaga K., 2007. Transformation of lake ecosystem into peat bog and vegetation history based on Durne Bagno mire (Lublin Polesie, E Poland). Geochronomet., 29, 23-47.

Bamforth S.S., Wall D.H. and Virginia R., 2001. Distribution and diversity of soil protozoa in the McMurdo Dry Valleys of Antarctica. Polar Biol., 28, 756-762.

Bateman L. and Davis C., 1980. Rotifera in hummock-hollow formation in poor (mesotrophic) fen in Newfoundland. Int. Rev. Hydrobiol., 65, 127-153.
Berzins B. and Pejler B., 1987. Rotifer occurrence in relation to pH. Hydrobiologia, 147, 107-116.

Bielańska-Grajner I., Cudak A. and Mieczan T., 2011. Epiphytic rotifer abundance and diversity in moss patches in bogs and fens in Polesie National Park (Eastern Poland). Int. Rev. Hydrobiol., 96, 29-38.

Bobrov A.B., Charman D.J. and Warner B.G., 1999. Ecology of Testate Amoebae (Protozoa: Rhizopoda) on peatlands in Western Russia with special attention to niche separation in closely related taxa. Protistologica., 150, 125-136.

Borcard D. and Vaucher von Ballmoos C., 1997. Oribatid mites (Acari, Oribatida) of a primary peat bog-palustre transition in the Swiss Jura mountains. Ecoscience, 4, 470-479.

Charman, D.J., Hendon D. and Woodland, W., 2000. The identification of testate amoebae (Protozoa: Rhizopoda) in peats. Quaternary Research Association, Technical Guide, UK, London, $147 \mathrm{p}$.

Clarke K.J., 2003. Guide to the Identification of Soil ProtozoaTestate Amoebae. Freshwater Biological Association, UK, Cumbria, $40 \mathrm{p}$.

Di Castri F., Hansen A.J. and Holland M.M., 1988. A new look at ecotones: emerging international projects on landscape boundaries. Biol. Int., 17, 1-163.

Finlay B.J. 1980. Temporal and vertical distribution of ciliophoran communities in the benthos of a small eutrophic loch with particular reference to the redox profile. Freshwater Biol., 10, 15-34.

Foissner W. and Berger H., 1996. A user-friendly guide to the ciliates (Protozoa, Ciliophora) commonly used by hydrobiologists as bioindicators in rivers, lakes and waste waters, with notes on their ecology. Freshwater Biol., 35, 375-470.

Foissner W., Berger H. and Kohmann F., 1994. Taxonomische und ökologische Revision der Ciliaten des Saprobiensystems. Hymenostomatida, Prostomatida, Nassulida. Informationsberichte des Bayer. Landesamtes für Wasserwirtschaft, München, 548 p.

Foissner W., Berger H. and Schaumburg J., 1999. Identification and Ecology of Limnetic Plankton Ciliates. Informationsberichte des Bayer. Landesamtes für Wasserwirtschaft, München, $800 \mathrm{p}$.

Gilbert D. and Mitchell E.A.D., 2006. Microbial diversity in Sphagnum peatlands. In: Martini I.P., Martinez Cortizas A. and Chesworth W. (eds.), Peatlands: Evolution and Records of Environmental and Climate Changes, Elsevier B.V., Amsterdam, 287-319.

Gilbert D., Amblard C., Bourdier G. and Francez A.J., 1998. The microbial loop at the surface of a peatland: structure, functioning and impact of nutrients inputs. Microbial Ecol., 35, 89-93.

Gilbert D., Amblard C., Bourdier G., Francez A.J. and Mitchell E.A.D., 2000. La régime alimentaire des thècamoebiens. Ann. Biol., 39, 57-68.

Golterman H.L., 1969. Methods for Chemical Analysis of Freshwaters, Blackwell Scientific Publications, Oxford, Edinburgh, 213 p.

Górniak A., Jakatierynczuk-Rudczyk E. and Dobrzyń P., 1999. Hydrochemistry of three dystrophic lakes in north-eastern Poland. Acta Hydroch. Hydrobiol., 27, 12-18.

Grolière C.A., 1975. Descriptions de quleques ciliés hypotriches des tourbières à sphaignes et des étendues d'eau acides. Protistologica, 11, 481-498. 
Grolière C.A., 1977. Contribution à l'étude de quelques ciliés des sphaignes: II - Dynamique des populations. Protistologica, $13,335-352$.

Grolière C.A., 1978. Contribution à l'étude des ciliés des sphaignes: III. Étude mathématique des résultats. Protistologica, 14, 295-311.

Heal O.W., 1964. Observations on the seasonal and spatial distribution of testacea (Protozoa: Rhizopoda) in Sphagnum. J. Anim. Ecol., 33, 395-412.

Herbichowa M. and Potocka J., 2004. Raised beatbogs with peat forming plants. Torfowiska wysokie z roślinnością torfotwórczą (żywe). Guide to Protection of Habitats and Species NATURA 2000, pp. 115-137.

Jassey E.J.V., Chiapusio G., Mitchell E.A.D., Binet P., Toussaint M.L. and Gilbert D., 2011. Fine-scale horizontal and vertical micro-distribution patterns of testate amoebae along a narrow fen/bog gradient. Microb. Ecol., 2, 374-385.

Jauhiainen S., 2002. Testacean amoebae in different types of mire following drainage and subsequent restoration. Eur. $J$. Protistol., 38, 59-72.

Kruk M., 2003. Biogeochemical multifunctionality of wetland ecotones in Lakeland agricultural landscape. Pol. J. Ecol., 2, 247-254.

Lamentowicz M. and Mitchell E.A.D., 2005. The ecology of Testate amoebae (Protists) in Sphagnum in north-western Poland in relation to peatland ecology. Microb. Ecol., 50, 48-63.

Lamentowicz M., Lamentowicz Ł., van der Knaap W.O., Gạbka M. and Mitchell E.A.D., 2010. Contrasting speciesenvironment relationships in communities of testate amoebae, bryophytes and vascular plants along the fen-bog gradient. Microb. Ecol., 59, 499-510.

Lepš J. and Šmilauer P., 2003. Multivariate Analysis of Ecological Data using CANOCO, Cambridge University Press, Cambridge, 269 p.

Meisterfeld R., 1977. Horizontal and vertical distribution of Testacea (Rhizopoda-Testacea) in Sphagnum. Arch. Hydrobiol., 79, 319-356.

Mieczan T., 2007. Epiphytic protozoa (Testate amoebae, ciliates) associated with Sphagnum in peatbogs: relationship to chemical parameters. Pol. J. Ecol., 55, 79-90.

Mieczan T., 2009a. Ciliates in Sphagnum peatlands: vertical micro-distribution, and relationships of species assemblages with environmental parameters. Zool. Stud., 1, 33-48.
Mieczan T., 2009b. Ecology of testate amoebae (Protists) in Sphagnum peatlands of eastern Poland: vertical microdistribution and species assemblages in relation to environmental parameters. Ann. Limnol. -Int. J. Limnol., 45, 41-49.

Mieczan T., 2010. Vertical micro-zonation of testate amoebae and ciliates in peatland waters in relation to potential food resources and grazing pressure. Int. Rev. Hydrobiol., 95, 86-102.

Mieczan T., 2012. Distributions of Testate amoebae and Ciliates in different types of peatlands and their contributions to the nutrient supply. Zool. Stud., 51, 1-9.

MVSP., 2002. Multivariate Statistical Package. Kovach Computering Services, Vales, UK.

Payne R.J., 2011. Can testate amoeba-based paleohydrology be extended to fens? J. Quat. Sci., 26, 15-27.

Payne R.J. and Mitchell E.A.D., 2007. Ecology of testate amoebae from mires in the Central Rhodope Mountains, Greece and development of transfer function for paleohydrological reconstruction. Protistologica, 158, 159-171.

Pejler B. and Berzins B., 1993. On the ecology of mire rotifers. Limnology, 23, 295-300.

Petz W., 1987. Ecology of the active soil microfauna (Protozoa, Metazoa) of Wilkes Land, East Antarctica. Polar Biol., 18, 33-44.

Pierce R.W. and Turner J.T., 1992. Ecology of plankton ciliates in marine food webs. Rev. Aquat. Sci., 6, 139-181.

Strüdel-Kypke M.C. and Schönborn W. 1999. Periphyton and sphagnicolous protists of dystrophic bog lakes (Brandenburg, Germany). II. Characteristic species and trophy of the lakes. Limnologica, 29, 407-424.

ter Braak C.J.F. and Šmilauer P., 2002. CANOCO Reference Manual and User's Guide to Canoco fof Windows: Software for Canonical Community Ordination (version 4.5). Microcomputer Power, Ithaca, NY, USA, $500 \mathrm{p}$.

Warner B.G. and Asada T., 2006. Biological diversity of peatlands in Canada. Aquat. Sci., 68, 240-253.

Warner B.G., Asada T. and Quinn N.P., 2007. Seasonal influences on the ecology of Testate amoebae (Protozoa) in a small Sphagnum peatland in southern Ontario, Canada. Microb. Ecol., 54, 91-100.

Wilkinson D.M. and Mitchell E.A.D., 2010. Testate amoebae and nutrient cycling with particular reference to soil. Geomicrobiol. J., 27, 520-533. 